rio para el desarrollo de proyectos de programación y planificación a medio y largo plazo. Como bien recuerdan los profesores Iglesias de Ussel, Castón Boyer y Alemán Bracho, este elemento constituye

\section{SOlÉ, Carlota}

\section{Modernidad y modernización}

Barcelona: Anthropos, 1998

Sota el títol de Modernidad y modernización, Carlota Solé publica la reedició revisada del seu llibre Modernización: un análisis sociológico ${ }^{1}$, en el qual ens ofereix una reflexió crítica de la proposta de definició de modernització que va elaborar l'any 1976. Tenint en compte el debat teòric en els camps de la filosofia i la sociologia entorn de la superació del procés de modernització i en relació amb l'assoliment d'una nova era -i.e. la postmodernitat-, Carlota Solé reflexiona sobre les transformacions econòmiques i socials que han afectat les societats occidentals més desenvolupades d'ençà de la dècada dels setanta.

En Modernización: un análisis sociológico, Carlota Solé elabora una proposta de definició operativa del concepte "modernització». Amb aital finalitat, inicia el seu estudi analitzant des d'una perspectiva crítica els enfocaments funcionalista, antropològic i marxista entorn del procés de canvi social denominat modernització. Dita anàlisi crítica es basa, d'una banda, en l'explicitació de tres de les objeccions constantment presents en els estudis sobre modernització (i.e. el relativisme, l'endogenisme i l'etnocentrisme), i de l'altra, a demostrar fins a quin punt la concepció de modernització porta intrínsecament la idea de progrés pròpia dels pensadors il.lustrats del segle XVIII. Al llarg del seu estudi, l'auto- uno de los grandes vacíos de nuestro país respecto a otros contextos nacionales.

Manuel Herrera Gómez
Universidad de Granada ra ha tingut present el context històric d'aparició de la noció de modernització, la fi del colonialisme i la propagació dels moviments d'alliberament nacional en els països colonitzats.

En síntesi, Carlota Solé critica el model bàsic de modernització transicional fonamentat en el model «abans-i-després» de R. Bendix, el qual implica l'acceptació de la idea d'un continuum entre els tipus polars de «tradició» i «modernitat». En aquest sentit, l'autora advoca per una concepció de modernitat no en termes d'estadi final o objectiu que cal assolir, sinó com a objectiu mòbil i variant -empíricament només existeixen societats «modernitzants» o en "via de modernització». A més, opta fermament per restringir el significat de modernització definint aquest procés de canvi social com la incorporació de la ciència i la tecnologia als assumptes humans per part de la intelligentsia indígena d'una societat. Carlota Solé argumenta la seua tesi afirmant que la innovació que caracteritza el procés de canvi social encunyat sota el terme de modernització és el desenvolupament ràpid i massiu de la ciència i la tecnologia, així com la seua extensió i aplicació a la vida quotidiana dels individus d'una societat determinada. En aital definició, l'agent modernitzador no és sinó la intelligentsia indígena (és a dir, el grup d'individus que desenvolupen una acti- 
vitat primordialment intel.lectual, o parcialment manual o tècnica, en la qual és necessari un cert grau de formació, d'entrenament o d'educació intel.lectual) que desitja modernitzar la seva societat; i.e. posar en pràctica el desenvolupament científic i tècnic, i aplicar-lo als assumptes humans. Per acabar, Carlota Solé emfasitza el paper clau de l'educació (entesa en un sentit ampli, no elitista), tant en la posada en pràctica de les innovacions cientificotècniques, com en la formació de les actituds i la mentalitat de l'ésser humà modern (actituds i mentalitat basades en la racionalitat i la secularització, ambdues definides seguint Weber).

Plantejada la proposta de definició operativa de modernització, Carlota Solé exposa succintament el debat dels anys vuitanta sobre la postmodernitat a fi de centrar-se, seguidament, en la reflexió sobre les aportacions més recents en teoria social entorn de la modernització ecològica, la modernització reflexiva i la societat de risc. Arran dels diversos desastres ecològics (problemes a les centrals nuclears, la pluja àcida, etc.), s'inicia un debat entorn de la progressiva agressió i destrucció de la naturalesa i la seua repercussió en la qualitat de vida de l'ésser humà. En aquest context, la modernització ecològica planteja una perspectiva optimista sobre el paper de la innovació cientificotecnològica en la prevenció de la destrucció del medi ambient.

En relació amb la preocupació ecològica, la crisi mediambiental és conceptualitzada no pas en termes somerament naturals, sinó emfasitzant llur caràcter social. Respecte d'això, autors tals com U. Beck, A. Giddens i N. Luhmann s'han esforçat a elaborar un marc conceptual que explique els efectes de la modernització, vigents avui dia. És en aquest sentit que conceptes com risc i reflexivitat apareixen en l'arena sociològica a mode d'eines heurístiques i implicant una nova forma d'aproximar-se a la realitat social a fi d'explicar-la i comprendre-la.
Carlota Solé conclou la revisió crítica sobre el seu estudi entorn de la modernització basant-se, sobretot, en les aportacions d'U. Beck, emmarcant històricament la validesa de l'esmentada proposta de definició de modernització -exposada a Modernización: un análisis sociológico- en l'època dels anys seixanta i setanta. D'ençà els vuitanta, l'anàlisi de la modernització ha de comportar un estudi més profund dels perills i riscos derivats de l'aplicació de la ciència i la tecnologia en la vida social, així com de la redefinició de l'agent modernitzador. En aquesta última qüestió, el protagonisme de la modernització reflexiva no recau en un únic grup social, sinó en cadascun dels individus que, conscients de llur posició en un món ple de riscos davant els quals no existeix cobertura, ni protecció possible, han desenvolupat un "posar-se en el món" reflexiu i crític. En el seu treball de revisió crítica del procés de canvi social denominat modernització, Carlota Solé esmenta fenòmens tan transcendents com la inclusió informacional i la globalització econòmica (seguint M. Castells), la incorporació de la dona al mercat laboral i les noves formes d'exclusió social. Tanmateix, l'element que preval en les definicions recents de la modernització sembla que és el paper central de la innovació cientificotecnològica en l'explicació de les transformacions socials. En paraules de Carlota Solé, «ja no és la raó com en l'època de la Il-lustració la que substitueix la religió com a sistema de creences i font de valors i normes, sinó la ciència i la confiança en la ciència com a referent cultural per a explicar (racionalitzar i justificar) els beneficis, però també els riscos i perills en tots els àmbits públics i privats de la vida social».

Així, doncs, Modernidad y modernización recull les diferents perspectives teòriques en relació amb el concepte de modernització al llarg dels últims quaranta anys. A més a més, reflecteix com el debat teòric sobre "modernització» i 
«modernitat» ha anat en la línia d'un apropament a la realitat social quotidiana. En aquest sentit, el mateix esforç de Carlota Solé a revisar la seua proposta de definició de modernització, tenint en compte les noves produccions teòriques en el camp de la reflexió sociològica i els recents esdeveniments històrics i canvis socials, va en aquesta direcció; i.e. l'aplicabilitat de la discussió teòrica entorn de grans conceptes, processos empírics de canvi social.

Kàtia Lurbe i Puerto 